\title{
PENGKAJIAN DAMPAK LINGKUNGAN TERHADAP AIR TANAH KOTA TANGERANG
}

\author{
Sri Subekti ${ }^{1 *}$ dan Sukaryo ${ }^{2}$ \\ ${ }^{1}$ Program Studi D3 Teknik Lingkungan Universitas Pandanaran Semarang \\ Jl. Banjarsari Barat No. 1 Tembalang Semarang 50275 \\ ${ }^{2}$ Program Studi D3 Teknik Kimia, Universitas Pandanaran Semarang \\ Jl. Banjarsari Barat No. 1 Tembalang Semarang 50275 \\ Email*: bek1_04@yahoo.com
}

\begin{abstract}
ABSTRAK
Perubahan lahan membawa dampak kepada perubahan sumberdaya air terutama air tanah. Air tanah merupakan penunjang utama disamping air permukaan dalam rangka memenuhi kebutuhan air bersih bagi penduduk Kota Tangerang. Perlindungan dan Pengelolaan Lingkungan Hidup bahwa setiap orang berhak atas lingkungan hidup yang baik dan sehat sebagai bagian dari hak asasi manusia. Kawasan Kota Tangerang yang banyak tertutupi oleh bangunan permukiman, gedung dan industri adalah di Kecamatan Cipondoh dengan luas 1,145.33 Ha dan Kecamatan Jatiuwung sebesar $361.86 \mathrm{Ha}$, kondisi ini tentunya akan berpengaruh terhadah air tanah di masa mendatang terutama air tanah dangkal karena daerah resapan yang semakin berkurang. Berdasarkan analisa permasalahan yang ada pada Kota Tangerang, perlu merencanakan penanganan lebih lanjut sebagai langkah perbaikan untuk konservasi atau pemeliharaan air tanah. Dan dari kondisi eksisting yang ada sekarang ini kita melakukan 3 tahap rencana tindakan yaitu tahap jangka pendek (perencanaan tahun 2017- 2024), tahap jangka menengah (perencanaan tahun 2024-2030), dan tahap jangka panjang (perencanaan tahun 2030-2037)
\end{abstract}

Kata Kunci: Dampak Lingkungan, Air Tanah, Konservasi, Rencana Tindak

\section{PENDAHULUAN}

Pembangunan yang sangat pesat di wilayah perkotaan dalam beberapa dekade terakhir ini menyebabkan adanya perubahan tata guna lahan dan berkurangnya pohon dan tanamantanaman sebagai penyerap air yang berpengaruh terhadap ketersediaan air dan terdegradasinya sumber-sumber air khususnya air tanah. Air merupakan sumber daya alam yang mudah terdegradasi fungsinya karena posisi geografis dan akibat penggunaan yang tidak sesuai dengan fungsi, peruntukan dan kemampuannya sehingga perlu dilindungi, dipulihkan dan dipelihara melalui upaya konservasi air tanah.

Menurut PP No 43 Tahun 2008 bahwa air tanah adalah air yang terdapat dalam lapisan tanah atau batuan di bawah permukaan tanah. Seiring dengan meningkatnya jumlah populasi penduduk Indonesia dalam dekade terakhir ini, maka kebutuhan akan air dengan sendirinya akan meningkat. Pertumbuhan populasi yang meningkat ini tidak diiringi dengan bertambahnya jumlah air di alam.

Menurut Undang-Undang nomor 32 tahun 2009 tentang Perlindungan dan Pengelolaan Lingkungan Hidup bahwa setiap orang berhak atas lingkungan hidup yang baik dan sehat sebagai bagian dari hak asasi manusia. Oleh karena itu, setiap orang berkewajiban memelihara kelestarian fungsi lingkungan hidup serta mengendalikan pencemaran dan/atau kerusakan lingkungan hidup.

Berdasarkan Undang - Undang nomor 37 tahun 2014 tentang Konservasi Tanah dan Air, tahapan awal upaya konservasi tanah dan air adalah perencanaan. Salah satu hal yang diperlukan dalam perencanaan konservasi sumber daya tanah dan air adalah pembuatan kesetimbangan air tanah untuk mengetahui kondisi sumber air tanah dan menghitung besarnya aliran air tanah yang selanjutnya menjadi acuan upaya 
pelaksanaan konservasi air tanah yang harus dilakukan di Kota Tangerang.

Berdasarkan kebijakan tersebut, pemerintah Kota Tangerang dengan visi LIVE (Liveable, Investible, Visitable dan E-City) yang salah satunya diwujudkan dengan melaksanakan perwujudan pembangunan yang berkelanjutan dan berwawasan lingkungan yang bersih, sehat dan nyaman. Salah satu langkah yang dilakukan oleh Pemerintah Kota Tangerang saat ini adalah berupaya dalam melakukan konservasi tanah dan air sebagai tahap awal konservasi khususnya terhadap air tanah dengan mengidentifikasi potensi dan perencanaan metoda konservasi yang sesuai dengan karakter air tanah di Kota Tangerang.

Perubahan lahan membawa dampak kepada perubahan sumberdaya air terutama air tanah, air tanah merupakan penunjang utama disamping air permukaan dalam rangka memenuhi kebutuhan air bersih bagi penduduk Kota Tangerang. Perubahan penggunaan lahan selain berpengaruh terhadap air tanah juga juga berpengaruh pada air permukaan, aliran air permukaan menjadi tidak terkendali perbedaan aliran air permukaan (surface run off) menjadi sangat jauh antara musim hujan dan musim kemarau, dimana pada musimhujan aliran air permukan yang tinggi melebihi kapasitas badan penampung air sehingga air meluap dan menimbulkan banjir, sedangkan pada musim kemarau air permukaan menunjukan ketinggian yang sangat rendah.

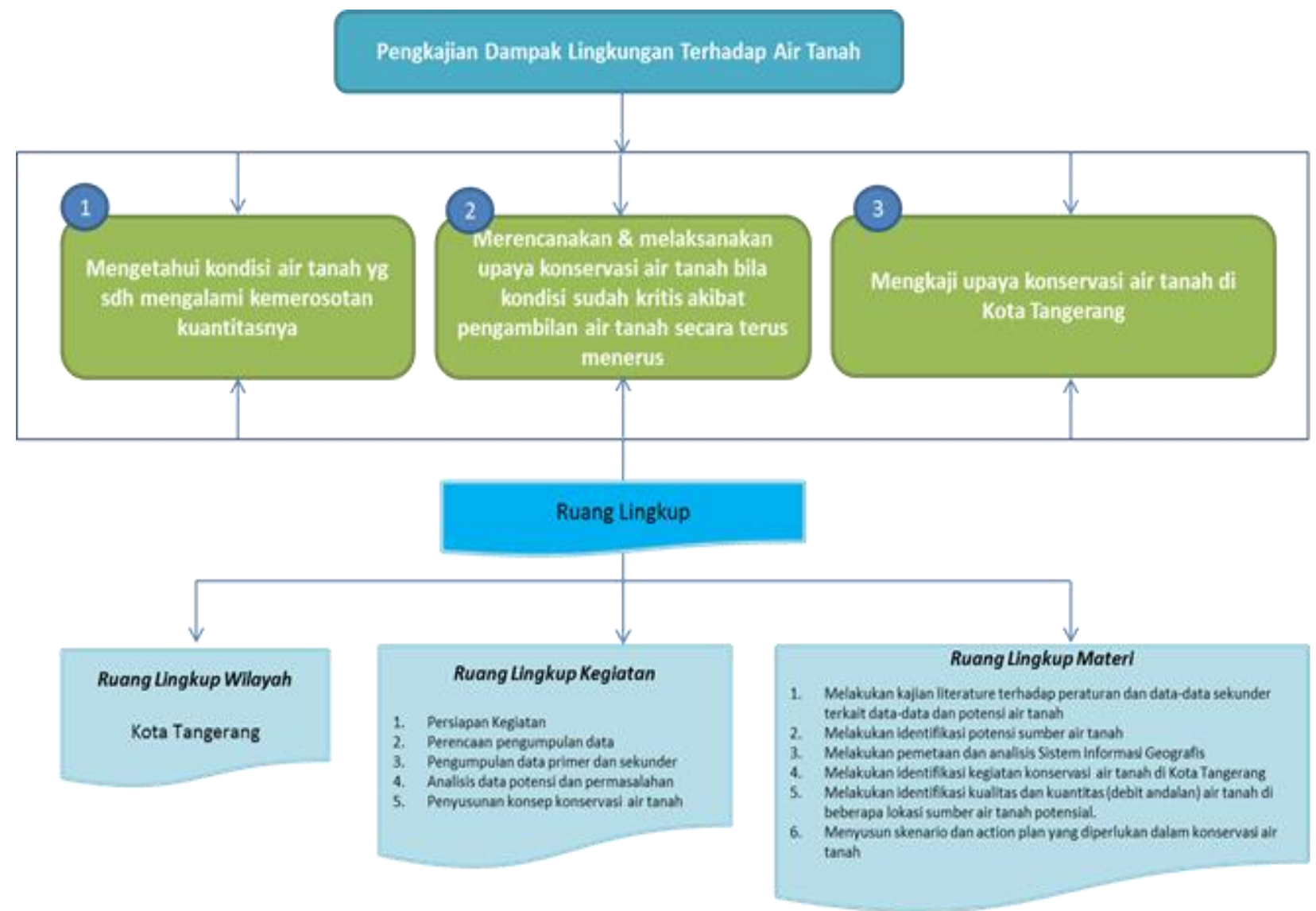

Gambar 1. Bagan Kegiatan Pengkajian Dampak Lingkungan Terhadap Air Tanah 


\section{METODE PENELITIAN}

Metode penelitian yang dilakukan, disajikan pada Gambar 2:

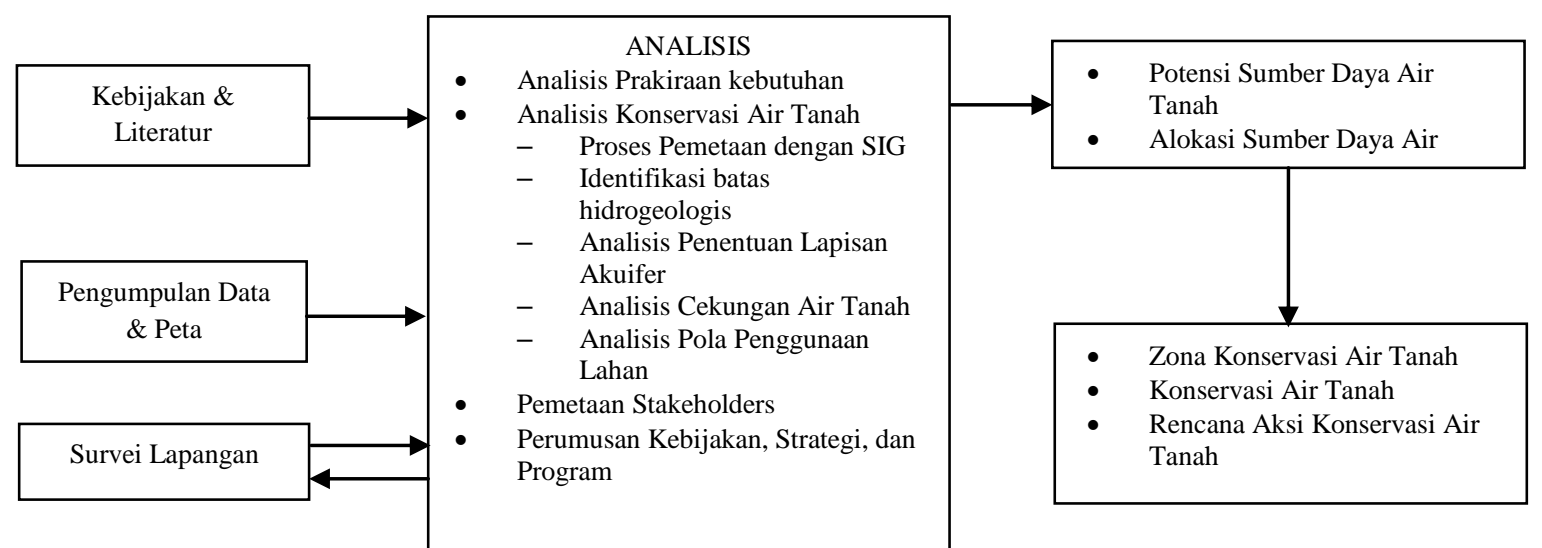

Gambar 2. Kerangka Berpikir Pengkajian Dapak Lingkungan Kota Tangerang

Permasalahan yang terjadi pada ketersediaan air tanah akibat pemanfaatan antara lain adalah sebagai berikut:

1. Peningkatan kebutuhan air yang meningkat seiring dengan pertambahan jumlah penduduk dan industri

2. Kesulitan masyarakat memperoleh air bersih terutama pada daerah yang kritis air

3. Ketergantungan yang tinggi terhadap air tanah

4. Keterbatasan kemampuan penyediaan air tanah karena banyaknya lahan terbangun dan berkurangnya kawasan resapan air

5. Terdapatnya pengambilan air tanah tanpa ijin (ilegal) (masyarakat, industry)

6. Kurangnya perhatian dalam konservasi air tanah (masyarakat, industry, pemerintah)

7. Kegiatan masyarakat yang mengakibatkan gangguan terhadap aliran sungai seperti penyempitan sungai, rusaknya tanggul sungai, cepatnya pendangkalan sungai akan menyebabkan banjir.

8. Masih dijumpai perilaku membuang sampah di sungai yang nantnya mengakibatkan penurunan kualtas air dan terjadinya sedimentasi

9. Sedimentasi tinggi akibat pesatnya pengembangan permukiman dan industri, berkurangnya areal hutan

10.Pasang air laut yang cenderung meningkat karena pemanasan global akan menyebabkan aliran balik (backwater) di sungai-sungai, selain menghambat aliran dari hulu yang berakibat banjir di daerah hilir seperti yang tarjadi saat ini, juga mengakibatkan meluasnya air payau hingga hulu yang rnempengaruhi sumber air baku.

11. Meningkatnya usaha pengeboran air tanah dapat mengakibatkan masuknya air laut ke dalam akuifer.

\section{HASIL DAN PEMBAHASAN}

Ketersediaan sumber daya alam secara kuantitas ataupun kualitas tidak merata, sedangkan kegiatan pembangunan membutuhkan sumber daya alam yang semakin meningkat. Kegiatan pembangunan juga mengandung risiko terjadinya pencemaran dan kerusakan lingkungan. Kondisi ini dapat mengakibatkan daya dukung, daya tampung, dan produktivitaslingkungan hidup menurun yang pada akhirnya menjadi beban sosial. Oleh karena itu, lingkungan hidup Indonesia harus dilindungi dan dikelola dengan baik berdasarkan asas tanggung jawab negara, asas keberlanjutan, dan asas keadilan. Selain itu, pengelolaan lingkungan hidup harus dapat memberikan kemanfaatan ekonomi, sosial, dan budaya yang dilakukan berdasarkan prinsip kehati-hatian, demokrasi lingkungan, desentralisasi, sertapengakuan dan penghargaan terhadap kearifan lokal dan kearifan lingkungan. 
Perlindungan dan pengelolaan lingkungan hidup menuntut dikembangkannya suatu system yang terpadu berupa suatu kebijakan nasional perlindungan dan pengelolaan lingkunganhidup yang harus dilaksanakan secara taat asas dan konsekuen dari pusat sampai ke daerah. Penggunaan sumber daya alam harus selaras, serasi, dan seimbang dengan fungsi lingkungan hidup. Sebagai konsekuensinya, kebijakan, rencana, dan/atau program pembangunan harus dijiwai oleh kewajiban melakukan pelestarian lingkungan hidup dan mewujudkan tujuanpembangunan berkelanjutan. Perlindungan dan pengelolaan lingkungan hidup bertujuan:

1. melindungi wilayah Negara Kesatuan Republik Indonesia dari pencemaran dan/atau kerusakan lingkungan hidup;

2. menjamin keselamatan, kesehatan, dan kehidupan manusia;

3. menjamin kelangsungan kehidupan makhluk hidup dan kelestarian ekosistem;

4. menjaga kelestarian fungsi lingkungan hidup;

5. mencapai keserasian, keselarasan, dan keseimbangan lingkungan hidup;

6. menjamin terpenuhinya keadilan generasi masa kini dan generasi masa depan;

7. menjamin pemenuhan dan perlindungan hak atas lingkungan hidup sebagai bagian dari hak asasi manusia;

8. mengendalikan pemanfaatan sumber daya alam secara bijaksana;

9. mewujudkan pembangunan berkelanjutan; dan 10.mengantisipasi isu lingkungan global.
Saat ini penggunaan lahan yang ada di Kawasan Kota Tangerang sebagian besar berupa area permukiman (perumahan), padang rumput dan untuk sawah irigasi, sedangkan sisanya dipergunakan untuk bangunan (industri, gedung dll), tanah ladang, pengisi area air (waduk, embung, sungai), landasan, semak belukar dan perkebunan. Untuk lahan yang tertutup oleh bangunan seperti area permukiman, bangunan dan landasan mempunyai luasan 9,872.11 $\mathrm{Ha}$ atau $54.24 .46 \%$ dari luas total Kota Tangerang, sedangkan sisanya $8,329.24 \mathrm{Ha}$ atau $45.76 \%$ berupa padang rumput, sawah irigasi, tanah ladang, pengisi area air, perkebunan dan semak belukar.

Kawasan Kota Tangerang yang banyak tertutupi oleh bangunan permukiman, gedung dan industri adalah di Kecamatan Cipondoh dengan luas 1,145.33 Ha dan Kecamatan Jatiuwung sebesar $361.86 \mathrm{Ha}$, kondisi ini tentunya akan berpengaruh terhadah air tanah di masa mendatang terutama air tanah dangkal karena daerah resapan yang semakin berkurang.

Konservasi air tanah sangat efektif jika dilakukan dengan menggunakan pendekatan geografi. Geografi memiliki tiga (3) macam pendekatan yang menjadi ciri khas dan kekuatan dalam menganalisi masalah di suatu wilayah, yaitu pendekatan keruangan, pendekatan kelingkungan, dan pendekatan kewilayahan. Adapun karakteristik dan aplikasi masing-masing pendekatan untuk konservasi air tanah di kota adalah dengan pendekatan keruangan, ekologi dan kewilayahan.

Tabel 1. Penggunaan Lahan di Kota Tangerang

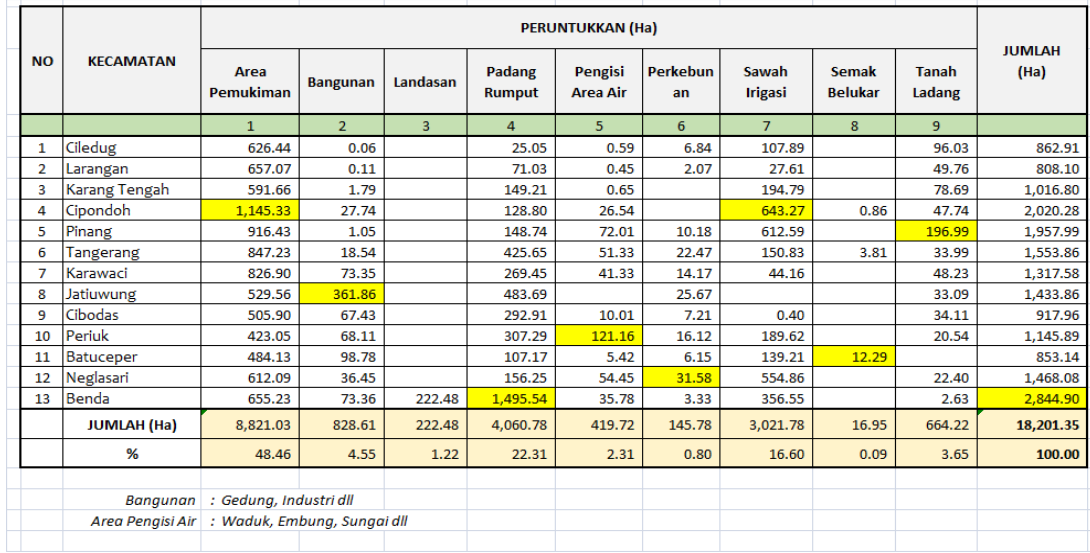

Sumber: Analisa Tahun 2017 
Dari tabel di atas dapat dilihat juga bahwa area yang tertutup oleh bangunan khususnya bangunan landasan lapangan terbang adalah di Kecamatan Benda, dengan luasan sebesar 222.48
Ha. Selanjutnya untuk luasan penggunaan lahan dan gambaran peta di masing-masing kecamatan dapat dilihat pada tabel dan gambar di bawah ini.

\begin{tabular}{c|l|r|r|}
\multicolumn{1}{c|}{$\mathbf{l}$} & Ciledug & & \\
\hline No & Penggunaan Lahan & Luas_Ha__ & Presentase $(\%)$ \\
\hline 1 & Area Pemukiman & 626.44 & 72.60 \\
\hline 2 & Bangunan & 0.06 & 0.01 \\
\hline 3 & Landasan & - & - \\
\hline 4 & Padang Rumput & 25.05 & 2.90 \\
\hline 5 & Pengisi Area Air & 0.59 & 0.07 \\
\hline 6 & Perkebunan & 6.84 & 0.79 \\
\hline 7 & Sawah Irigasi & 107.89 & 12.50 \\
\hline 8 & Semak Belukar & - & - \\
\hline 9 & Tanah Ladang & 96.03 & 11.13 \\
\hline & Total & 862.91 & 100.00 \\
\hline
\end{tabular}

\begin{tabular}{c|l|r|r|}
\hline $\mathbf{2}$ & Larangan & & \\
\hline No & Penggunaan Lahan & Luas_Ha_- & Presentase (\%) \\
\hline 1 & Area Pemukiman & 657.07 & 81.31 \\
\hline 2 & Bangunan & 0.11 & 0.01 \\
\hline 3 & Landasan & - & - \\
\hline 4 & Padang Rumput & 71.03 & 8.79 \\
\hline 5 & Pengisi Area Air & 0.45 & 0.06 \\
\hline 6 & Perkebunan & 2.07 & 0.26 \\
\hline 7 & Sawah Irigasi & 27.61 & 3.42 \\
\hline 8 & Semak Belukar & - & - \\
\hline 9 & Tanah Ladang & 49.76 & 6.16 \\
\hline & Total & 808.10 & 100.00 \\
\hline & & &
\end{tabular}

\begin{tabular}{|c|c|c|c|}
\hline 3 & Karang Tengah & & \\
\hline No & Penggunaan Lahan & Luas_Ha_ & Presentase $(\%)$ \\
\hline 1 & Area Pemukiman & 591.66 & 58.19 \\
\hline 2 & Bangunan & 1.79 & 0.18 \\
\hline 3 & Landasan & - & - \\
\hline 4 & Padang Rumput & 149.21 & 14.67 \\
\hline 5 & Pengisi Area Air & 0.65 & 0.06 \\
\hline 6 & Perkebunan & - & - \\
\hline 7 & Sawah Irigasi & 194.79 & 19.16 \\
\hline 8 & Semak Belukar & - & - \\
\hline \multirow[t]{2}{*}{9} & Tanah Ladang & 78.69 & 7.74 \\
\hline & Total & $1,016.80$ & 100.00 \\
\hline
\end{tabular}

\begin{tabular}{c|l|r|r|}
\hline $\mathbf{4}$ & Cipondoh & & \\
\hline No & Penggunaan Lahan & Luas_Ha__ & Presentase (\%) \\
\hline 1 & Area Pemukiman & $1,145.33$ & 56.69 \\
\hline 2 & Bangunan & 27.74 & 1.37 \\
\hline 3 & Landasan & - & - \\
\hline 4 & Padang Rumput & 128.80 & 6.38 \\
\hline 5 & Pengisi Area Air & 26.54 & 1.31 \\
\hline 6 & Perkebunan & - & - \\
\hline 7 & Sawah Irigasi & 643.27 & 31.84 \\
\hline 8 & Semak Belukar & 0.86 & 0.04 \\
\hline 9 & Tanah Ladang & 47.74 & 2.36 \\
\hline & Total & $2,020.28$ & 100.00
\end{tabular}

\begin{tabular}{c|l|r|r|}
\hline $\mathbf{5}$ & Pinang & & \\
\hline No & Penggunaan Lahan & Luas_Ha__ & Presentase (\%) \\
\hline 1 & Area Pemukiman & 916.43 & 46.80 \\
\hline 2 & Bangunan & 1.05 & 0.05 \\
\hline 3 & Landasan & - & - \\
\hline 4 & Padang Rumput & 148.74 & 7.60 \\
\hline 5 & Pengisi Area Air & 72.01 & 3.68 \\
\hline 6 & Perkebunan & 10.18 & 0.52 \\
\hline 7 & Sawah Irigasi & 612.59 & 31.29 \\
\hline 8 & Semak Belukar & - & - \\
\hline 9 & Tanah Ladang & 196.99 & 10.06 \\
\hline & Total & $1,957.99$ & 100.00 \\
\hline
\end{tabular}

Tabel 2.Luasan Penggunaan Lahan

\begin{tabular}{|c|l|r|r|}
6 & Tangerang & & \\
\hline No & Penggunaan Lahan & Luas_Ha_ & Presentase (\%) \\
\hline 1 & Area Pemukiman & 847.23 & 54.52 \\
\hline 2 & Bangunan & 18.54 & 1.19 \\
\hline 3 & Landasan & - & - \\
\hline 4 & Padang Rumput & 425.65 & 27.39 \\
\hline 5 & Pengisi Area Air & 51.33 & 3.30 \\
\hline 6 & Perkebunan & 22.47 & 1.45 \\
\hline 7 & Sawah Irigasi & 150.83 & 9.71 \\
\hline 8 & Semak Belukar & 3.81 & 0.25 \\
\hline 9 & Tanah Ladang & 33.99 & 2.19 \\
\hline & Total & $1,553.86$ & 100.00 \\
\hline
\end{tabular}

\begin{tabular}{|c|c|c|c|}
\hline 7 & Karawaci & & \\
\hline No & Penggunaan Lahan & Luas_Ha & Presentase (\%) \\
\hline 1 & Area Pemukiman & 826.90 & 62.76 \\
\hline 2 & Bangunan & 73.35 & 5.57 \\
\hline 3 & Landasan & - & - \\
\hline 4 & Padang Rumput & 269.45 & 20.45 \\
\hline 5 & Pengisi Area Air & 41.33 & 3.14 \\
\hline 6 & Perkebunan & 14.17 & 1.08 \\
\hline 7 & Sawah Irigasi & 44.16 & 3.35 \\
\hline 8 & Semak Belukar & - & - \\
\hline 9 & Tanah Ladang & 48.23 & 3.66 \\
\hline & Total & $1,317.58$ & 100.00 \\
\hline
\end{tabular}

\begin{tabular}{|c|c|c|c|}
\hline 11 & Batuceper & & \\
\hline No & Penggunaan Lahar & Luas_(Ha) & Presentase (\%) \\
\hline 1 & Area Pemukiman & 484.13 & 56.75 \\
\hline 2 & Bangunan & 98.78 & 11.58 \\
\hline 3 & Landasan & - & - \\
\hline 4 & Padang Rumput & 107.17 & 12.56 \\
\hline 5 & Pengisi Area Air & 5.42 & 0.64 \\
\hline 6 & Perkebunan & 6.15 & 0.72 \\
\hline 7 & Sawah Irigasi & 139.21 & 16.32 \\
\hline 8 & Semak Belukar & 12.29 & 1.44 \\
\hline 9 & Tanah Ladang & - & - \\
\hline & Total & 853.14 & 100.00 \\
\hline
\end{tabular}

\begin{tabular}{|c|c|c|c|}
\hline 12 & Neglasari & & \\
\hline No & Penggunaan Lahar & Luas $\mathrm{Ha}$ & Presentase (\%) \\
\hline 1 & Area Pemukiman & 612.09 & 41.69 \\
\hline 2 & Bangunan & 36.45 & 2.48 \\
\hline 3 & Landasan & - & - \\
\hline 4 & Padang Rumput & 156.25 & 10.64 \\
\hline 5 & Pengisi Area Air & 54.45 & 3.71 \\
\hline 6 & Perkebunan & 31.58 & 2.15 \\
\hline 7 & Sawah Irigasi & 554.86 & 37.80 \\
\hline 8 & Semak Belukar & - & - \\
\hline 9 & Tanah Ladang & 22.40 & 1.53 \\
\hline & Total & $1,468.08$ & 0.00 \\
\hline
\end{tabular}

\begin{tabular}{|c|l|c|c|}
\hline $\mathbf{8}$ & Jatiuwung & & \\
\hline No & Penggunaan Lahan & Luas_Ha__ & Presentase (\%) \\
\hline 1 & Area Pemukiman & 529.56 & 36.93 \\
\hline 2 & Bangunan & 361.86 & 25.24 \\
\hline 3 & Landasan & - & - \\
\hline 4 & Padang Rumput & 483.69 & 33.73 \\
\hline 5 & Pengisi Area Air & - & - \\
\hline 6 & Perkebunan & 25.67 & 1.79 \\
\hline 7 & Sawah Irigasi & - & - \\
\hline 8 & Semak Belukar & - & - \\
\hline 9 & Tanah Ladang & 33.09 & 2.31 \\
\hline & Total & $1,433.86$ & 100.00 \\
\hline
\end{tabular}

\begin{tabular}{|c|c|c|c|}
\hline 9 & Cibodas & & \\
\hline No & Penggunaan Lahan & Luas ( $\mathrm{Ha})$ & Presentase (\%) \\
\hline 1 & Area Pemukiman & 505.90 & 55.11 \\
\hline 2 & Bangunan & 67.43 & 7.35 \\
\hline 3 & Landasan & - & - \\
\hline 4 & Padang Rumput & 292.91 & 31.91 \\
\hline 5 & Pengisi Area Air & 10.01 & 1.09 \\
\hline 6 & Perkebunan & 7.21 & 0.79 \\
\hline 7 & Sawah Irigasi & 0.40 & 0.04 \\
\hline 8 & Semak Belukar & - & - \\
\hline 9 & Tanah Ladang & 34.11 & 3.72 \\
\hline & Total & 917.96 & 00.00 \\
\hline
\end{tabular}

\begin{tabular}{|c|c|c|c|}
\hline 10 & Periuk & & \\
\hline No & Penggunaan Lahan & Luas_Ha & Presentase $(\%)$ \\
\hline 1 & Area Pemukiman & 423.05 & 36.92 \\
\hline 2 & Bangunan & 68.11 & 5.94 \\
\hline 3 & Landasan & - & - \\
\hline 4 & Padang Rumput & 307.29 & 26.82 \\
\hline 5 & Pengisi Area Air & 121.16 & 10.57 \\
\hline 6 & Perkebunan & 16.12 & 1.41 \\
\hline 7 & Sawah Irigasi & 189.62 & 16.55 \\
\hline 8 & Semak Belukar & - & - \\
\hline 9 & Tanah Ladang & 20.54 & 1.79 \\
\hline & Total & $1,145.89$ & 100.00 \\
\hline
\end{tabular}

\begin{tabular}{|c|c|c|c|}
\hline 12 & Benda & & \\
\hline No & Penggunaan Lahar & Luas_(Ha) & Presentase (\%) \\
\hline 1 & Area Pemukiman & 655.23 & 23.03 \\
\hline 2 & Bangunan & 73.36 & 2.58 \\
\hline 3 & Landasan & 222.48 & 7.82 \\
\hline 4 & Padang Rumput & $1,495.54$ & 52.57 \\
\hline 5 & Pengisi Area Air & 35.78 & 1.26 \\
\hline 6 & Perkebunan & 3.33 & 0.12 \\
\hline 7 & Sawah Irigasi & 356.55 & 12.53 \\
\hline 8 & Semak Belukar & - & - \\
\hline 9 & Tanah Ladang & 2.63 & 0.09 \\
\hline & Total & $2,844.90$ & 100.00 \\
\hline
\end{tabular}




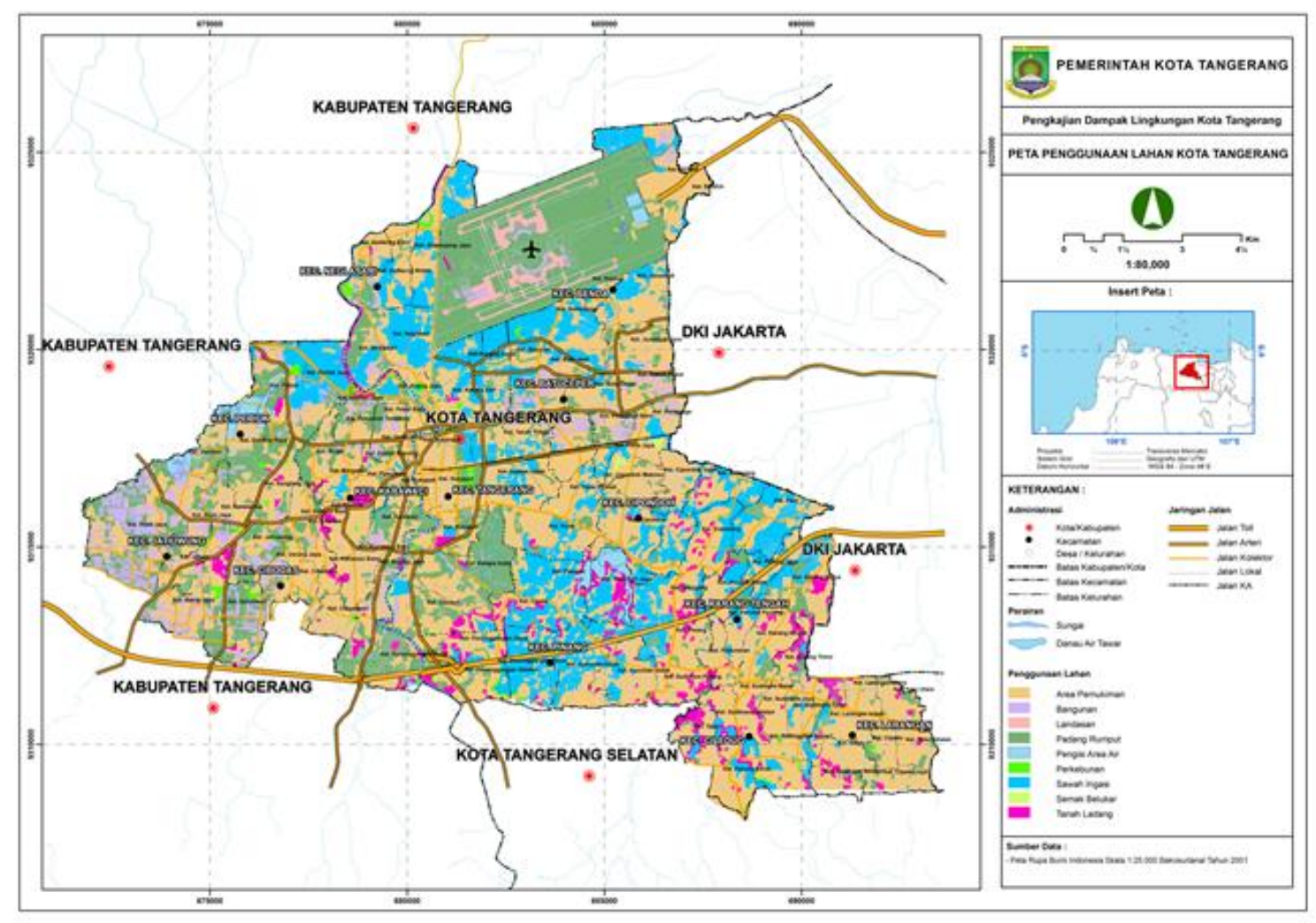

Gambar 3. Peta Tata Guna Lahan Kota Tangerang

Tabel 3. Proyeksi Jumlah Penduduk Kota Tangerang 2017-2035

\begin{tabular}{|c|c|c|c|c|c|c|c|c|c|c|c|c|c|c|c|c|c|c|c|}
\hline \multirow{2}{*}{10} & \multicolumn{19}{|c|}{ 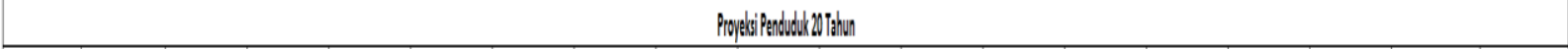 } \\
\hline & 2019 & 2010 & 2019 & 200 & 201 & 202 & 2013 & 2024 & 2015 & 206 & 201 & 2018 & 200 & 20 & 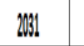 & 202 & 203 & 2044 & 2035 \\
\hline 1 loanglengha & 14,62638 & $145,77,6$ & 1990,5:5.2. & (2002] & 8433 & 60.14 & 1650,01033 & 169266599 & 17364270 & $\mid 88,1447$ & 18270988 & $187,423,14$ & 19,259:27] & 197,19956 & 20230783 & 207527,37 & 2228851.57 & $288,3732$. & 224007.9 \\
\hline 2 Cimorom & $30,43,49$ & 366,65350 & 331,92517 & $377,665.11$ & 364371.17 & 38966560 & 40,5220 & 49997.78 & 40,00467 & 45.65954 & $1401,10.13$ & 507,56616 & $532,4,49$ & 557,50035 & 586,0094 & 613,383989 & 1333.10 & 64,45656 & 109802 \\
\hline 3 Prang & $266,4661$. & 244142524 & 22201712 & 2020966 & $38870 \mathrm{Nan}$ & 27752260 & 2560658.81. & $266116 \mathrm{OA}$ & 25,95552 & 286,1775 & 2667550 & 307,22282 & 3889711. & $30,7,4,15$ & 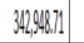 & 3555035.52 & 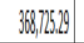 & $32 / 331.25$ & 66928 \\
\hline 4 Togerargy & 181,6866. & 1862680.4 & 19,1,13650 & 1959972,A & 20942,77 & 2060689.9. & 211362,3 & $266,73,62$ & 2213323,02 & 280,040 & 233851566 & 39988826 & 25,597812 & 2751.16 & $258,334.4$ & 35680 & 5012 & $9,117,16$ & 6262. \\
\hline 5 Marlad & 180,15307 & 187,7560.1. & $185,373.07$ & 187,042535 & 18866999 & 190301011 & 19998944 & 199670430 & $195,376,64$ & 1979999.9 & 19882213 & 20,58216 & 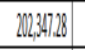 & $20,127,94$ & $205,94,66$ & 20,73640 & 209564,48 & 211406696 & 21376902 \\
\hline 6 daturng & 122,03828. & 1226260.12 & 125,56676 & $1227,7,4,5$ & 12303181.87 & 132320,24 & 123594,15 & 12398606 & 12468200 & 124329.14 & 124592.13 & 1248658.87 & 12551,1466 & 125,37600 & 125690009 & $125,93,394$ & $166,683,4$ & 6339 & 126698900 \\
\hline colots & 1557,7634 & 157,1966 & $1597,38,15$ & 160178310 & 1688392.2 & 165595.125 & $168075,1,3$ & 10026,96 & $127,45,0.0$ & 174622149 & 16687753 & 19,1111.18 & 181.43830 & 715.77 & 186077,46 & $1,592.5$ & 8153 & 3331468 & 789.11.1. \\
\hline 8 peridk & 188713,76 & 1517,720.9. & 159721213 & 157782625 & 161,155696 & 1642725.5. & 16675439 & 109926.63 & 191437858 & 17788559 & 18.159015 & 185,10638 & $188872 \mathrm{M}$ & $19,622,4$ & $196,194,15$ & $20,43,68$ & 20497260 & 208585250 & $2775,0.1$. \\
\hline 9 Btwengen & $12,72,14$ & 10,56650 & 1064979.2 & 184460. & 110380868 & 112366664 & 1440046 & 166711.12 & 118599.5 & 100,7554 & 12990606 & 1251,13535 & 127,402030 & 129,0625 & 132,253939 & 134,411 & 1368717.54 & 1393551013 & $14,8 / 3 / 3$ \\
\hline 10 llegagai & $118,80.37$ & 100324,42 & 122611.10 & 124990.70 & 12734545 & 12973356 & $132,981.49$ & 1377702066 & 137,6976 & 13987788 & 14,55556 & $145,263,74$ & $18,0,337$ & $150,85.54$ & 153,60093 & 15560087 & 1995762.8 & 106260823 & $1656,69,79$ \\
\hline 11 Rends & $10,41.156$ & 10432626 & 1077887.1. & $10,492.20$ & 11965698 & 1169992,20 & 120387,13 & 1239882.5 & $127,700,2.2$ & 13146163] & 13:977:12.3 & 138808539 & 1409,9307 & 147,75755 & 1551322.22 & 1557,1056 & 100,2617 & 16487272.2 & 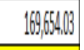 \\
\hline werosy & 19,90929 & Whiswil & 2112601,8 & 299942.87 & $20,0,062,2$ & {$[6 x, 595,1,10$} & $4 x, 1.12 .60$ & $20 \times, 5, y=50$ & 26092129 & 80,06060 & {$[1, j, y, 2]$} & 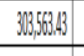 & $336(6,4989$ & $34,14,1.3$ & $32,4,3,2.3$ & $30,601.1 .5$ & 31,28686 & 386546463 & $42,[53.80$ \\
\hline 13 |armang & 20124,13 & $207,585.5$ & $2137,130$. & $20,182,13$ & 2665021.1 & 233,66.97 & 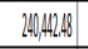 & 20763217.1 & $255,5390.9$ & 202660.17 & $200,55,55$ & $288,032.15$ & 26693569 & $255,53130.1$ & 304348855 & 33134488 & 322,2100 & 332,47353 & $34,44,30$ \\
\hline lotat Ingerang & 4,58932525 & 201685620 & $2477,245.55$ & 23397,2024 & 2,440399100 & 2,471202036 & $25,0,353.73$ & 260188.107 & $2685,99.69$ & 2702330.100 & 284,582828 & 2926494213 & 3008353,47 & 305616364 & $3,187,75: 50$ & 3281.200 .64 & 33787366,68 & $3499,4,46$ & 350430.08 \\
\hline
\end{tabular}


Tabel 4 Proyeksi Jumlah Kebutuhan air yang diambil oleh penduduk di Kota Tangerang 2017- 2035

\begin{tabular}{|c|c|c|c|c|c|c|c|c|c|c|c|c|c|c|c|c|c|c|c|}
\hline & \multicolumn{19}{|c|}{ 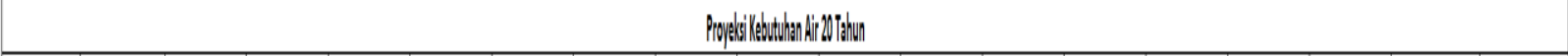 } \\
\hline & 2019 & 2018 & 209 & 100 & MI & 201 & MII & 204 & MS & $W 6$ & MOI & 208 & WO & 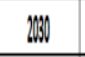 & M. & M. & 紅 & W & MS \\
\hline 1 longer & $22,45,507$ & 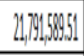 & 2.353982:25.2 & 249095,54009 & 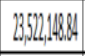 & 24,19000028) & $2,775,5,490.2$ & 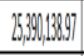 & 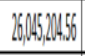 & 2083 & 1324 & 81:1350.87 & 2888890,14 & 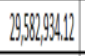 & $30346,1732$. & 31,129161010 & 31992,25012 & 607870 & 33601,19477 \\
\hline 2 Cimonon & 216523 & 4 & 197708602, & $54,19,7612,2$ & $3607,75,53$ & 5,99798936 & 60076935556 & 02999606093 & 1488 & (1) & $\pi$ & & & 889925,52808 & 87 & 9 & 86 & $7,780.13$ & 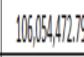 \\
\hline 3 Panerg & & 3. & 33. & 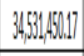 & $35906,60.606$ & 37,1268005050 & 30,4 & 399. & $4,390,38606$ & 4.9 & & & & 49. & 5. & 33 & 53308,9356 & 8086 & 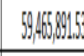 \\
\hline 4 Tagrearg & (2),9. & 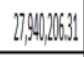 & 28656175.59 & 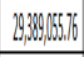 & $30,14,4,5,59$ & 30991205358 & $31,7,4,49,55$ & $36560,2,2,3]$ & $33,344,53,12$ & $3400,1352.2$ & 35077,1916 & 39975,79554 & 368 & 37, & 38 & 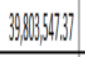 & 8819 & 6757465 & 4,9939345 \\
\hline 5 | (bandari & 27329290 & $27,56,042,15$ & 279695900.8 & 20,06062625 & 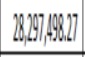 & 18556565666 & $28797,75,50$ & $20,01,1,5,59$ & 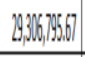 & 205546555.77 & 29846464,19 & $30,87,73250$ & $30532,12,265$ & 36,691901046 & 30808603934 & $31,160,59360$ & $31,346,120$ & 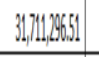 & 319935592 \\
\hline 6 Jitung & 183057.1. & 1833901016 & 183775,5466 & 1846,16804- & $18,64,70,607$ & 18995,55350 & 18552,37213 & 18571.29.1.1. & 1860028998. & 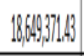 & 1860855351.1 & 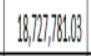 & 18767,19397 & 1809652530 & 188640,1399 & 1808559562 & 18996,650636 & 1896493939 & 190049898 \\
\hline 7 Cowoss & 13,35895: & B. & $23900,(6,68)$ & 246617,6609 & 24550,08024,4 & $24982,607,16$ & 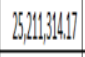 & 25.5240102899 & 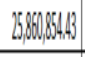 & 269198,8357 & 165.5 & 1680 & $2 \pi$ & 27589860360 & 27916,6828 & 18626890756 & 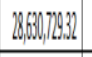 & 97,2066 & 036 \\
\hline 8 perink & $22307,1,64$ & $20,75,45594$ & 23,212802000 & 235993997.80 & $24,55,5352,8$ & 2640,86539 & 25,5615000: & $26,64,394,78$ & $66,156,76000$ & 26602582823 & $27,2$. & 21765956,28 & B8. & 28 & Q & 300 & 9964 & 87374.53 & 31.9 \\
\hline Atureser & N1.1. & $15,587,9$ & 15991,9717.1. & 16661:9972. & $16.6553,34,1,17$ & 16850959590 & $191,1007,1.33$ & $17,70,68062$. & $17,768087,72$ & 18108802039 & 1835600012 & 18770,301268 & 191 & 19. & 19 & 2016 & 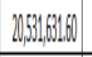 & 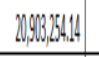 & 428 \\
\hline 10 legegsedic & 177,22126 & 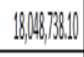 & 1839160641.3 & $18,4,1,157,4$ & 19997,18675 & $19,40,0,3330$ & $19987,73.93$ & Wol653964 & $20,590,65300$ & 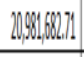 & $243030,34,160$ & 21,76560104. & $22,0,56,00$ & 226023,5350 & 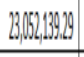 & 33,49,1999, & 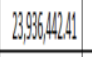 & 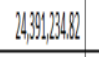 & 2485460202 \\
\hline 11 Bonto & 152111,33 & 155628736.60 & 16,16066049 & 1657394,455 & 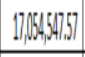 & $17,59,12,155$ & 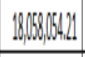 & $18582,137,18$ & 1912060617] & 19651,1588. & $20,456,53020$ & 208218087:1: & 24,63600016 & 20158682010. & 20680,32324 & 13355658997] & $24,339,49.9$. & $2,730988.3$ & 15.54,150) \\
\hline 12 cledsy & 00136201 & $30,38,0,079$ & $31,600,1.199$ & $33,994,-40,38$ & 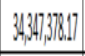 & 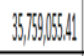 & 37,287525259 & 38778686432 & 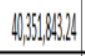 & 40,010303099 & $43,76907,1,9$ & 45,53451521. & $47,166,962,18$ & 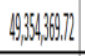 & 5.3280834313 & 33,4960800 & 5569399690 & $5,9020,43,13$. & 6036535606 \\
\hline 13 arogenn & 1600 & 31,162675939 & $320165,5951: 58$ & $330,5,5,4,13$ & $340,6,652$. & 350,999175 & $3606671: 150$ & $37,4,75,18.8$ & 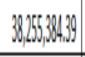 & 39999212038 & $4,5,7,15,0,07$ & $4,79,5,7,1,5$ & 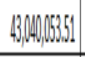 & $4,466551.11$ & $15,562) 36655$ & $47,0,731,53$ & 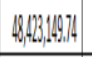 & 4891,10.92. & $53,302,40$ \\
\hline 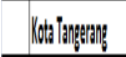 & 89345 & 2426858500 & 207120.45 & 23398,244 & $2,4397,100$ & 2971203036 & $250,35,13$ & 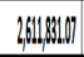 & 268,9796 & 27823010.0 & 284.5828 & 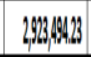 & $30083,3.4$ & 30610304 & 3180,050 & 380.1250 .4 & 397878680 & $349,4,4 B$ & 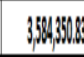 \\
\hline
\end{tabular}

Tabel 5. Sebaran Sumur Dalam di Kota tangerang

\section{KATAGORI : SUMUR DALAM}

\begin{tabular}{|c|c|c|c|c|c|c|c|c|c|c|c|c|c|c|c|c|c|c|c|c|c|c|c|c|}
\hline \multirow[b]{2}{*}{ No } & \multirow[b]{2}{*}{ Kecamatan } & \multirow[b]{2}{*}{\begin{tabular}{|c|} 
Jum \\
Kelura \\
han
\end{tabular}} & \multicolumn{7}{|c|}{ Kedalaman } & \multirow[b]{2}{*}{ JML } & \multicolumn{13}{|c|}{ Peruntukan } & \multirow[b]{2}{*}{ JML } \\
\hline & & & $40-75$ & $76-100$ & 101_125 & $126-150$ & $151-17$ & $176-200$ & $\begin{array}{l}\text { Tdk } \\
\text { ada } \\
\text { data }\end{array}$ & & $\begin{array}{c}\text { Hidra } \\
\text { nt }\end{array}$ & $\begin{array}{l}\text { Lingk } \\
\text { Sekitar }\end{array}$ & MCK & $\begin{array}{c}\text { MCK \& } \\
\text { Air } \\
\text { Minum }\end{array}$ & $\begin{array}{c}\text { MCK\& } \\
\text { Boiler }\end{array}$ & $\begin{array}{l}\text { MCK \& } \\
\text { Kolam } \\
\text { Renang }\end{array}$ & $\begin{array}{c}\text { MCK\& } \\
\text { Operasi } \\
\text { onal }\end{array}$ & $\begin{array}{c}\text { MCK\& } \\
\text { Produks } \\
i\end{array}$ & $\begin{array}{c}\text { MCK, } \\
\text { Pabrik \& } \\
\text { Mess }\end{array}$ & $\begin{array}{c}\text { MCK, } \\
\text { Mall \& } \\
\text { Mess }\end{array}$ & $\begin{array}{l}\text { Perawat } \\
\text { an Lingk }\end{array}$ & $\begin{array}{c}\text { Produk } \\
\text { si }\end{array}$ & $\begin{array}{l}\text { Tdk } \\
\text { ada } \\
\text { data }\end{array}$ & \\
\hline 1 & Ciledug & 8 & & 1 & & & & & & 1 & & & & & & & 1 & & & & & & & 1 \\
\hline 2 & Larangan & 8 & & 2 & & & & & & 2 & & & 1 & & & & & 1 & & & & & & 2 \\
\hline 3 & Karang Tengah & 7 & & 3 & 1 & & & & & 4 & & & 3 & & & 1 & & & & & & & & 4 \\
\hline 4 & Cipondoh & 10 & & 1 & 2 & 1 & & & & 4 & & & 2 & & & & & 2 & & & & & & 4 \\
\hline 5 & Pinang & 11 & & 1 & & 1 & & & & 2 & & & 1 & & & & & 1 & & & & & & 2 \\
\hline 6 & Tangerang & 8 & & 9 & 4 & 5 & & & & 18 & & & 11 & 1 & & & & 6 & & & & & & 18 \\
\hline 7 & Karawaci & 16 & 3 & 10 & 10 & 8 & & & & 31 & & & 20 & & & & 1 & 7 & & & & & 3 & 31 \\
\hline 8 & Jatiuwung & 6 & 5 & 25 & 36 & 20 & 1 & 5 & & 92 & & & 52 & & 1 & & & 36 & 1 & 1 & & 1 & & 92 \\
\hline 9 & Cibodas & 6 & 4 & 8 & 4 & 4 & & & 2 & 22 & & 1 & 10 & & & & & 9 & & & 1 & & 1 & 22 \\
\hline 10 & Periuk & 5 & 2 & 3 & 10 & 11 & & & & 26 & & & 17 & & & & & 9 & & & & & & 26 \\
\hline 11 & Batuceper & 7 & 1 & 1 & 8 & 8 & 2 & & & 20 & 1 & & 18 & & & & & & & & & 1 & & 20 \\
\hline 12 & Neglasari & 7 & 1 & 4 & 3 & & & & & 8 & & & 5 & & & & & 3 & & & & & & 8 \\
\hline \multirow[t]{2}{*}{13} & Benda* & 5 & 1 & 5 & 4 & 4 & & & & 14 & & & 5 & & & & & 8 & & & & 1 & & 14 \\
\hline & & & 17 & 73 & 82 & 62 & 3 & 5 & 2 & 244 & 1 & 1 & 145 & 1 & 1 & 1 & 2 & 82 & 1 & 1 & 1 & 3 & 4 & 244 \\
\hline
\end{tabular}


Dari Tabel di atas dapat dilihat, tingkat kedalaman dari 244 titik sumur dalam yang digunakan adalah dari 40 - $200 \mathrm{~m}$, sebanyak 234 titik sumur dalam (96\%) berada di kedalaman 40 $150 \mathrm{~m}$ dan 8 titik sumur dalam (3\%) di kedalaman 151 - $200 \mathrm{~m}$ (Ctt: 2 titik sumur dalam tidak ada data). Sebaran dari 244 titik sumur dalam tersebut, sekitar 92 titik sumur dalam $(38 \%)$ berada di Kecamatan Jatiuwung, 31 titik sumur dalam (13\%) berada di Kecamatan Karawaci, 26 titik sumur dalam (11\%) berada di Kecamatan Periuk, 22 titik sumur dalam (9\%) berada di Kecamatan Cibodas, 20 titik sumur dalam $(8 \%)$ berada di Kecamatan Batuceper dan sisanya sekitar 53 titik sumur dalam (22\%) menyebar di kecamatan lainnya. Peruntukan sumur dalam ini oleh perusahaan digunakan untuk keperluan: Hidrant, Lingkungan sekitar, MCK, MCK \& Air Minum, MCK \& Boiler, Kolam Renang, MCK \& Operasional, MCK \& Produksi, MCK, Pabrik \& Mess, MCK, Mall \& Mess, Perawatan Lingkungan, dan Produksi.

Sedangkan peruntukan yang paling banyak digunakan adalah untuk keperluan MCK, yaitu sebanyak 145 titik sumur dalam (59\%) dan 82 titik sumur dalam untuk MCK dan Produksi (34\%).

Tabel 6. Sebaran Sumur Pantek di Kota Tangerang

KATAGORI : SUMUR PANTEK

\begin{tabular}{|c|c|c|c|c|c|c|c|c|c|c|c|c|c|c|c|c|c|c|c|c|c|c|c|}
\hline \multirow[b]{2}{*}{ No } & \multirow[b]{2}{*}{ Kecamatan } & \multirow[b]{2}{*}{$\begin{array}{c}\text { Jum } \\
\text { Kelurahan }\end{array}$} & \multicolumn{5}{|c|}{ Kedalaman } & \multirow[b]{2}{*}{$J M L$} & \multicolumn{14}{|c|}{ Peruntukan } & \multirow[b]{2}{*}{ JML } \\
\hline & & & $9-20$ & $21-40$ & $41-60$ & $61-80$ & $\begin{array}{c}\text { Tdk ada } \\
\text { data }\end{array}$ & & Hidrant & $\begin{array}{l}\text { Lingk } \\
\text { Sekitar }\end{array}$ & MCK & $\begin{array}{c}\text { MCK\& } \\
\text { Air } \\
\text { Minum }\end{array}$ & $\begin{array}{c}\text { MCK \& } \\
\text { Boiler }\end{array}$ & $\begin{array}{l}\text { MCK\& } \\
\text { Kolam } \\
\text { Renang }\end{array}$ & $\begin{array}{c}\text { MCK\& } \\
\text { Operasio } \\
\text { nal }\end{array}$ & $\begin{array}{c}\text { MCK\& } \\
\text { Produks } \\
\mathrm{i}\end{array}$ & $\begin{array}{c}\text { MCK, } \\
\text { Cuci } \\
\text { Mobil }\end{array}$ & \begin{tabular}{|c|} 
MCK, \\
Pabrik \& \\
Mess \\
\end{tabular} & $\begin{array}{c}\text { MCK, } \\
\text { Mall \& } \\
\text { Mess }\end{array}$ & $\begin{array}{l}\text { Perawat } \\
\text { an Lingk }\end{array}$ & $\begin{array}{c}\text { Produ } \\
\text { ksi }\end{array}$ & $\begin{array}{c}\text { Tdk ada } \\
\text { data }\end{array}$ & \\
\hline & & & & & & & & & & & & & & & & & & & & & & & \\
\hline 1 & Ciledug & 8 & & 2 & & & & 2 & & & 1 & & & & 1 & & & & & & & & 2 \\
\hline 2 & Larangan & 8 & & 1 & 1 & & & 2 & & & 2 & & & & & & & & & & & & 2 \\
\hline 3 & Karang Tengah & 7 & & 2 & & & & 2 & & & 1 & & & & 1 & & & & & & & & 2 \\
\hline 4 & Cipondoh & 10 & 1 & 6 & & & & 7 & & & 4 & & & & & 1 & 2 & & & & & & 7 \\
\hline 5 & Pinang & 11 & 1 & 4 & 1 & & & 6 & & & 6 & & & & & & & & & & & & 6 \\
\hline 6 & Tangerang & 8 & 8 & 3 & 2 & & & 13 & & & 12 & & & & & 1 & & & & & & & 13 \\
\hline 7 & Karawaci & 16 & 2 & 36 & 14 & 1 & & 53 & & & 50 & & & 1 & & 1 & 1 & & & & & & 53 \\
\hline 8 & Jatiuwung & 6 & 30 & 106 & 17 & 3 & & 156 & & & 142 & & & & & 11 & 1 & & & & & 2 & 156 \\
\hline 9 & Cibodas & 6 & 4 & 14 & 2 & & 1 & 21 & & & 17 & & & & & 3 & & & & & & 1 & 21 \\
\hline 10 & Periuk & 5 & 5 & 20 & 6 & 4 & & 35 & & & 35 & & & & & & & & & & & & 35 \\
\hline 11 & Batuceper & 7 & 10 & 36 & 10 & 4 & & 60 & & & 53 & & & & & 4 & 1 & & & & 1 & 1 & 60 \\
\hline 12 & Neglasari & 7 & 16 & 15 & & & & 31 & & & 31 & & & & & & & & & & & & 31 \\
\hline \multirow[t]{2}{*}{13} & Benda ${ }^{*}$ & 5 & 12 & 16 & 7 & 5 & & 40 & & & 36 & & & & & 4 & & & & & & & 40 \\
\hline & & & 89 & 261 & 60 & 17 & 1 & 428 & 0 & 0 & 390 & 0 & 0 & 1 & 2 & 25 & 5 & 0 & 0 & 0 & 1 & 4 & 428 \\
\hline
\end{tabular}

Dari Tabel di atas untuk katagori sumur pantek, tingkat kedalaman dari 428 titik sumur pantek yang digunakan adalah dari 9 - $80 \mathrm{~m}$, sebanyak 350 titik sumur pantek $(82 \%)$ berada di kedalaman 9 - $40 \mathrm{~m}$ dan 78 titik sumur pantek (18\%) di kedalaman 41 - 80 m. Sebaran dari 428 titik sumur pantek tersebut, sekitar 156 titik sumur pantek (36\%) berada di Kecamatan Jatiuwung, 60 titik sumur pantek (14\%) berada di Kecamatan Batuceper, 53 titik sumur pantek (12\%) berada di Kecamatan Karawaci, 40 titik sumur pantek (9\%) berada di Kecamatan Benda, 35 titik sumur pantek (8\%) berada di Kecamatan Periuk, 31 titik sumur pantek $(7 \%)$ berada di Kecamatan Neglasari dan sisanya sekitar 53 titik sumur pantek (12\%) menyebar di kecamatan lainnya. Peruntukan sumur dalam ini oleh perusahaan digunakan untuk keperluan: MCK, Kolam Renang, MCK \& 
Operasional, MCK \& Produksi, MCK \& Cuci Mobil dan Produksi.

Peruntukan yang paling banyak digunakan oleh perusahaan adalah untuk keperluan MCK, yaitu sebanyak 390 titik sumur pantek (91\%) dan 25 titik sumur pantek untuk MCK dan Produksi $(6 \%)$.

Ada 4 (empat) katagori dalam zona konservasi air tanah pada sistem aquifer tertekan atas (kedalaman $40-140$ mbt), di Kota Tangerang, yaitu:

\section{Aman}

Ditandai dengan penurunan muka piezometrik $<40 \%$ dan nilai DHL air tanah $<100$ mikromosh/cm. Penggunaan air tanah untuk kebutuhan pokok sehari-hari dan pertanian rakyat, diijinkan masing-masing dengan debit maksimum 100 m3/bulan per KK dan 20 ltr/detik per KK.

2. Rawan

Ditandai dengan penurunan muka piezometrik antara 40 - $60 \%$ dan nilai DHL air tanah antara $1000-1500$ mikromosh $/ \mathrm{cm}$. Penggunaan air tanah untuk kebutuhan pokok sehari-hari dan pertanian rakyat, diijinkan masingmasing dengan debit maksimum $100 \mathrm{~m} 3 /$ bulan per KK dan 20 ltr/detik per KK.

3. Kritis

Ditandai dengan penurunan muka piezometrik antara 60 - $80 \%$ dan nilai DHL air tanah antara 1500 - 5000 mikromosh $/ \mathrm{cm}$. Penggunaan air tanah untuk kebutuhan pokok sehari-hari dan pertanian rakyat tidak diijinkan. Debit maksimum yang diijinkan 100 m3/bulan per KK dan 20 ltr/detik per KK.

4. Rusak

Ditandai dengan penurunan muka piezometrik antara $>80 \%$ dan nilai DHL air tanah antara $>5000 \mathrm{mikromosh} / \mathrm{cm}$. Penggunaan air tanah baru untuk pelbagai keperluan tidak diijinkan kecuali untuk kebutuhan sehari-hari perorangan. Debit pengambilan air tanah yang dijinkan tidak melebihi 100 m3/bulan per KK.

Dari data peta yang ada, sebesar $32.46 \%$ kawasan Kota Tangerang dalam zona aman, 48.24\% dalam zona rawan, $19.07 \%$ dalam zona kritis dan 3,23\% dalam zona rusak. Pada zona kritis, dua kecamatan yang masuk dalam zona kritis cukup besar, yaitu Kecamatan Tangerang sebesar 1,378.68 Ha dan Kecamatan Neglasari sebesar 763.86 Ha. Pada zona rawan, kecamatan yang masuk dalam kawasan rawan dengan luasan yang cukup besar adalah Kecamatan Benda seluas 2,799.09 Ha, Kecamatan Cipondoh seluas 1,902.64 Ha dan Kecamatan Karang Tengah seluas 1,016.80 Ha. Sedangkan pada zona rusak, terdapat tiga kecamatan yang kawasannya masuk dalam zona rusak, yaitu Kecamatan Neglasari seluas $567.09 \mathrm{Ha}$, Kecamatan Jatiuwung seluas 10.77 Ha dan Kecamatan Cibodas seluas 10.34 Ha.

\section{Rencana Tindak}

Setelah melihat berbagai permasalahan dan analisa masalah yang ada pada Kota Tangerang, perlu merencanakan penanganan lebih lanjut sebagai langkah perbaikan untuk konservasi atau pemeliharaan air tanah. Dan dari kondisi eksisting yang ada sekarang ini kita melakukan 3 tahap rencana tindakan yaitu Tahap jangka pendek (perencanaan tahun 2017- 2024) dan Tahap jangka menengah (perencanaan tahun 2024-2030) serta tahap jangka panjang (perencanaan tahun 2030-2037).

A. Rencana Jangka Pendek

1. Membuat sumur peresapan yang disesuaikan dengan kondisi geologi atau pemanfaatan lahan-lahan kosong masyarakat sebagai area resapan air. Sumur resapan merupakan sistem resapan buatan yang berfungsi sebagai penampung air hujan, dapat berupa sumur, parit atau alur taman resapan

2. Memelihara daerah resapan air dan kawasan sabuk hijau dengan harapan nantinya dapat menjaga konservasi sumber airnya

3. Melakukan inventarisasi tempat pengambilan air baku

4. Memperbaiki jaringan hidrologi

5. Melakukan upaya pemulihan DAS secara terpadu serta meningkatkan daya dukung DAS dengan mencegah kerusakan dan memperbaiki daerah tangkapan air sebagai daerah resapan air (misal: pembuatan terasering dan sumur resapan) maupun vegetatif

6. Melaksanakan program pembangunan situ, embung dan waduk

7. Melakukan sosialisasi gerakan hemat air

8. Meningkatkan komunikasi, informasi serta edukasi untuk meningkatkan kesadaran masyarakat dalam pengelolaan lingkungan 
B. Rencana Jangka Menengah

1. Membuat sumur peresapan yang disesuaikan dengan kondisi geologi atau pemanfaatan lahan-lahan kosong masyarakat sebagai area resapan air. Sumur resapan merupakan sistem resapan buatan yang berfungsi sebagai penampung air hujan, dapat berupa sumur, parit atau alur taman resapan

2. Memelihara daerah resapan air, sabuk hijau sehingga nantinya dapat menjaga konservasi sumber daya air.

3. Memperhatikan water resources

4. Mengembangkan teknologi dam parit yang dibangun pada alur sungai untuk menambah kapasitas tampung sungai, memperlambat laju aliran dan meresapkan air ke dalam tanah (recharging).

5. Menjaga sumber air yang ada dari pencemaran air dengan cara pengelolaan limbah cair sebelum dibuang ke badan air, pengelolaan sampah dengan skala rumah tangga.

6. Menjaga kawasan hutan atau penghijauan yang terdapat di kawasan sekitar sumber air dengan harapan kuantitas air tetap bagus.

7. Melaksanakan program pembangunan situ, embung dan waduk

8. Melakukan sosialisasi gerakan hemat air

9. Memasukkan pendidikan pelestarian lingkungan hidup dan sumber daya alam ke dalam kurikulum pendidikan nasional.

C. Rencana Jangka Panjang

1. Untuk menjaga kelestarian potensi air sumur maka setiap warga diharuskan mengadakan penghijauan di masing-masing rumah

2. Membuat sumur resapan, dengan harapan pada musim penghujan dapat menyimpan air sebanyak mungkin sehingga di musim kemarau dapat digunakan.

3. Setiap warga masyarakat sudah mulai membuat Penampungan Air Hujan (PAH) sehingga pada musim kemarau air hujan ini dapat digunakan.

4. Memperhatikan water resources sehingga air yang digunakan nantinya dapat digunakan secara berkelanjutan

5. Pembatasan jumlah sumur bor dan pembatasan jumlah penggunaan sumur bor bagi kepentingan non rumah tangga dalam skala besar (industri, perdagangan, jasa, dan lainlain) karena penggunaan sumur bor dapat membahayakan sumber mata air yang ada di sekitarnya, menyebabkan penurunan tanah, dan intrusi air laut.

6. Perlu dilakukan pemantauan muka air tanah untuk setiap sistem akuifer dengan terlebih dahulu menetapkan jaringan sumur pantau yang terencana.

7. Perlindungan air tanah dari unsur pencemar perlu diupayakan karena limbah cair yang mengalir di sungai dapat langsung meresap ke akuifer dangkal.

8. Melaksanakan program pembangunan situ, embung dan waduk.

9. Melakukan sosialisasi gerakan hemat air.

10. Memasukkan pendidikan pelestarian lingkungan hidup dan sumber daya alam ke dalam kurikulum pendidikan nasional.

\section{SIMPULAN}

Beberapa upaya yang bisa dilakukan sebagai upaya untuk pemeliharaan air tanah sehingga nantinya bsa digunakan secara berkelanjutan dapat dilakukan dengan berbagai upaya:

1. Pengelolaan kawasan lindung dan penyangga, melalui penegakan hukum setiap pelanggaran perubahan fungsi lahan, upaya insentif disinsentif hulu-hilir, konservasi DAS, penanganan teknis dan non teknis

2. Konservasi metode vegetatif, yaitu melalui proses intersepsi dan proses infiltrasi. Proses intersepsi mengkondisikan curah hujan yang jatuh dengan intensitas tinggi namun berdurasi singkat dapat terserap tajuk dan diubah menjadi aliran batang dan tetesan langsung sehingga berdurasi panjang dengan intensitas rendah.

3. Melakukan penghijauan dengan menentukan sistem perakaran dan jenis tanaman yang sesuai sehingga bahan organik dapat tumbuh secara alami menciptakan biopori sehingga meningkatkan porositas tanah. Dengan demikian kapasitas infiltrasi (resapan) tanah akan semakin meningkat. Jumlah air yang terserap tanah dan tertangkap akuifer akan tertahan dan secara bertahap dilepaskan dalam bentuk mata air.

4. Mengatur siklus hidrologi agar air hujan dapat disimpan di dalam profil tanah sebanyak dan selama mungkin dan mengatur siklus hidrologi agar air tidak menimbulkan bencana 
5. Melibatkan masyarakat yang tinggal di hulu DAS untuk ikut serta dalam kegiatan konservasi serta pembentukan pemberdayaan masyarakat peduli kawasan hijau baik itu hutan kota atau hutan lindung.

6. Pengambilan air tanah dalam harus melalui ijin dinas terkait karena hak ini akan menyangkut penurunan air tanah mendukung perlndungan mata air

7. Memelihara dan melindungi sumber air yang ada yaitu dengan cara menjaga air dari pencemaran dan memperbaiki kualitas air tercemar, menggunakan dan memanfaatkan air secara tepat dan tdk berlebihan, memanen air hujan dengan membuat tampungan misal membuat Penampungan Air Hujan

8. Membuat sumur resapan dirancang dapat menampung dan meresapkan air hujan dari atap bangunan, dan dari limpasan permukaan di pekarangan yang tidak tercampur oleh air buangan rumah tangga. Sumur resapan dibangun dalam kawasan permukiman, secara kelompok maupun individu, sarana pendidikan dan pada instansi pemerintah

\section{SARAN}

Dari berbagai permasalahan yang ada dalam zona konseravsi di Kota Tangerang dan rencana yang perlu dilakukan, maka ada beberapa rekomendasi yang perlu dilakukan sebagai upaya untuk pemeliharaan air tanah sehingga nantinya bisa digunakan secara berkelanjutan, diantaranya adalah:

1. Pengelolaan kawasan lindung dan penyangga, melalui penegakan hukum setiap pelanggaran perubahan fungsi lahan, upaya insentif disinsentif hulu-hilir, konservasi DAS, penanganan teknis dan non teknis.

2. Konservasi metode vegetatif, yaitu melalui proses intersepsi dan proses infiltrasi. Proses intersepsi mengkondisikan curah hujan yang jatuh dengan intensitas tinggi namun berdurasi singkat dapat terserap tajuk dan diubah menjadi aliran batang dan tetesan langsung sehingga berdurasi panjang dengan intensitas rendah.

3. Melakukan penghijauan dengan menentukan sistem perakaran dan jenis tanaman yang sesuai sehingga bahan organik dapat tumbuh secara alami menciptakan biopori sehingga meningkatkan porositas tanah. Dengan demikian kapasitas infiltrasi (resapan) tanah akan semakin meningkat. Jumlah air yang terserap tanah dan tertangkap akuifer akan tertahan dan secara bertahap dilepaskan dalam bentuk mata air.

4. Mengatur siklus hidrologi agar air hujan dapat disimpan di dalam profil tanah sebanyak dan selama mungkin dan mengatur siklus hidrologi agar air tidak menimbulkan bencana

5. Melibatkan masyarakat yang tinggal di hulu DAS untuk ikut serta dalam kegiatan konservasi serta pembentukan pemberdayaan masyarakat peduli kawasan hijau baik itu hutan kota atau hutan lindung.

6. Pengambilan air tanah dalam harus melalui ijin dinas terkait karena hak ini akan menyangkut penurunan air tanah mendukung perlndungan mata air

7. Memelihara dan melindungi sumber air yang ada yaitu dengan cara menjaga air dari pencemaran dan memperbaiki kualitas air tercemar, menggunakan dan memanfaatkan air secara tepat dan tdk berlebihan, memanen air hujan dengan membuat tampungan misal membuat Penampungan Air Hujan

8. Membuat sumur resapan dirancang dapat menampung dan meresapkan air hujan dari atap bangunan, dan dari limpasan permukaan di pekarangan yang tidak tercampur oleh air buangan rumah tangga. Sumur resapan dibangun dalam kawasan permukiman, secara kelompok maupun individu, sarana pendidikan dan pada instansi pemerintah

\section{DAFTAR PUSTAKA}

Peraturan Daerah Kota Tangerang No. 2 Tahun 2009 tentang Pengelolaan Lingkungan Hidup.

Peraturan Daerah Kota Tangerang No. 2 tahun 2013 tentang Pengelolaan Kualitas Air dan Pengendalian Pencemaran Air.

Peraturan Pemerintah Nomor 42 tahun 2008 tentang Pengelolaan Sumber Daya Air.

Undang-undang Nomor 32 Tahun 2009 tentang Perlindungan dan Pengelolaan Lingkungan Hidup. 
Undang-Undang Nomor 37 Tahun 2014 tentang Konservasi Tanah dan Air. 